\title{
Effects of distal limb ice bag cryotherapy in horses - a thermographic evaluation
}

\author{
H. H. Florian Buchner und Gerlinde Wiesenhofer
}

Clinic for Horses, Department of Companion Animals and Horses, University of Veterinary Medicine Vienna, Austria

\begin{abstract}
Summary
This experimental study evaluated the cooling effect of ice bag cryotherapy on the hoof surface temperature in horses. In 6 horses one forelimb was cooled for 90 minutes using an ice water bag system applied between the carpus and the hooves, while the contralateral hoof served as control. Surface temperature of the hooves was determined using thermography before, during cooling and for 90 minutes following the end of cooling. Coronary and mid wall temperature was evaluated during the time course and compared with the contralateral hoof temperature. At 60 and 90 min cooling had a significant, but very small cooling effect of $1.4{ }^{\circ} \mathrm{C}$ at the coronary band, while at mid wall no significant temperature change was found. The cooling effect of three tightly fitting ice water bags around fetlock and cannon bone was only small. As this method acted by cooling the distal limb with the supplying arterial blood rather than the hoof itself, the hoof surface temperature probably underestimated the laminar temperature in an unknown extent. Ice bags do have the advantage, that they can be used also in horses, which should be allowed to lie down, like horses suffering from severe laminitis. However, these cooling effects are far from cooling effects of ice water immersion in rubber boots and possibly not effective for therapeutic purposes in laminitic horses.
\end{abstract}

Keywords: Cryotherapy / thermography / laminitis / horse

\section{Wirkung einer Eisbeutel-Kryotherapie an der distalen Gliedmaße bei Pferden: eine thermographische Studie}

In diese experimentelle Studie wurde die Auswirkung der Applikation von Icepacks an der distalen Extremität auf die Oberflächentemperatur von Hufen ermittelt. Zu diesem Zweck wurden 6 lahmheitsfreien Pferden jeweils 3 lcepacks zirkulär um die linke Vorderextremität angebracht und mit einer Kunststoffgamasche gesichert, sie reichten von der Fessel bis zum proximalen Drittel des Metacarpus. Die Icepacks wurden aus Rektalhandschuhen gefertigt und mit jeweils $600 \mathrm{~g}$ Crasheis und $200 \mathrm{ml}$ Wasser gefüllt. Nach einer Applikationszeit von - 1, 10 , 20, 40, 60 und 90 Minuten, sowie zu den Zeitpunkten 10, 20, 40, 60 und 90 Minuten nach Abnahme der Icepacks wurden von dorsal und lateral Thermogramme angefertigt und an der Hufoberfläche im Bereich der Krone und auf halber Hufhöhe jeweils die Temperatur ermittelt. Die gewählte Methode der Eisapplikation wurde von allen 6 Pferden gut toleriert und erwies sich als praktikabel und robust gegen Beschädigung oder Verlust. Eine signifikante Temperatursenkung konnte sowohl im Vergleich zum Ausgangswert der behandelten Extremität, als auch im Vergleich mit der unbehandelten rechten Kontrollextremität nur nach 60 und 90 Minuten Anwendungszeit an der Messregion an der Krone erzielt werden, wobei der maximal an der Oberfläche gemessene Temperaturabfall im Vergleich zur Ausgangstemperatur 1.39 $(p=0.03)$ und im Vergleich zur Kontrollextremität $2.04(p=0.02)$ betrug. Die Temperaturveränderungen auf Mitte der Hufhöhe erreichten zu keinem Zeitpunkt signifikante Werte. Die mittels Thermographie erhobenen, aufgrund der indirekten Kühlung über das zuströmende Blut erreichten Temperaturdifferenzen an der Oberfläche der Hornkapsel waren also nur sehr gering. Diese geringe Differenz war mit hoher Wahrscheinlichkeit auf die guten isolierenden Eigenschaften des Hufhornes zurückzuführen. Dennoch wurde an der Hufoberfläche eine signifikante Abkühlung erreicht, die darauf deutet, dass die im Inneren der Hufmatrix erzielte Temperatursenkung wesentlich deutlicher und wahrscheinlich klinisch relevant ist. Um eine endgültige Bestätigung der klinischen Relevanz zu erhalten wären Messungen mit in die Hufmatrix implantierten Nadelthermistoren in Betracht zu ziehen und Studien an akut an Hufrehe erkrankten Pferden durchzuführen.

Schlüsselwörter: Kryotherapie / Thermographie / Rehe / Pferd

\section{Introduction}

Laminitis, though well known for millennia as major crippling or killing disease of horses, is still a major problem in equine medicine (USDA 2000) and a major research focus. Besides an intense scientific effort on the pathophysiology of the disease (Moore and Belknap 2009), many different therapeutic means are used and evaluated (Belknap 2010, van Eps 2010a). One of the most effective means to prevent laminitis is the use of cryotherapy (van Eps and Pollitt 2004). Probably reducing the local metabolism and thereby avoiding the effects of the inflammatory cascade within the hoof, cryotherapy used for 48 or 72 hours during the developmental phase has proven to prevent manifest laminitis in the experimental model (van Eps and Pollitt 2004, van Eps and Pollitt 2009). However, several problems impede the successful use of cryotherapy in the clinical setting. Often the pathologic process within the laminae has already caused irreparable damage when the horse is presented for therapy. Even horses with conditions that predispose for laminitis, such as in endotoxic horses, like colic, diarrhea or metritis, the practicability of limb cooling as a preventive measure may be difficult in these critically ill horses. During an acute phase of laminitis, lying down of the animal is beneficial to unload the hooves and thereby reduce the tearing forces on the laminae, but this is impossible while standing in icewater devices.

Various devices have been tried and used for distal limb cryotherapy, such as cold pack or wraps, standing in cold creeks, ice water boots and buckets, although each method presents advantages and disadvantages (van Eps 2010b). 
Ice water immersion has been proven to be the most effective means in cooling the distal limb (Kaneps 2000, Kasashima 2001, Pollitt and van Eps 2004, Turner et al. 1991, Worster et al. 2000), however, this can only be applied in the standing horse. Similarly, prototype devices applying refrigerated coo-
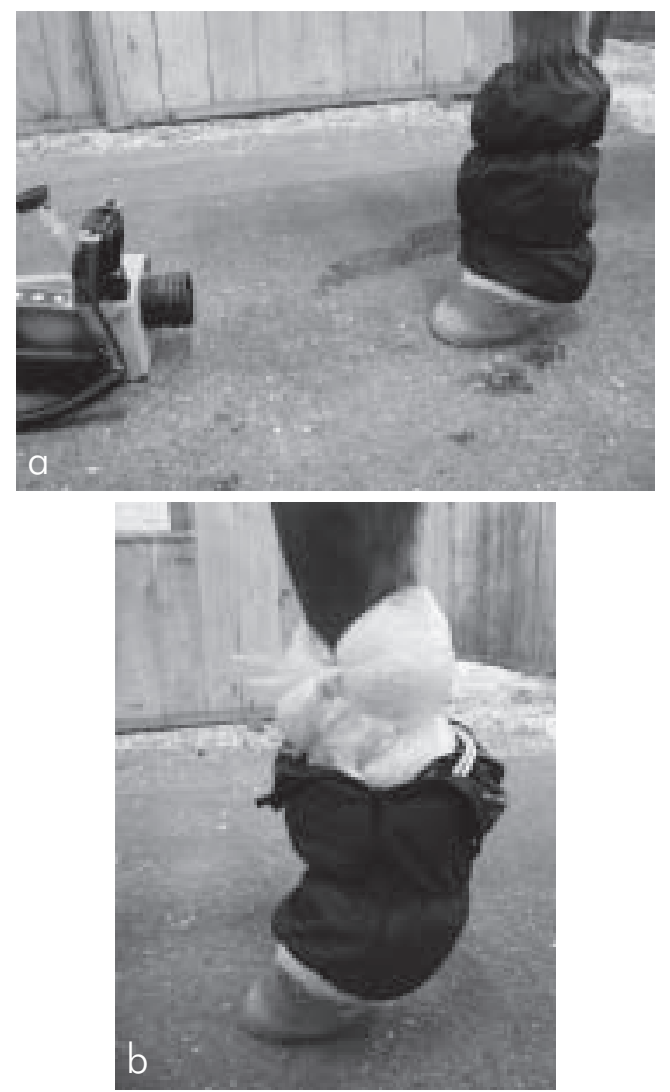

Fig. 1 a Hoof with icebags and gaiter and thermocamera, b Ice bags with open gaiter

lant to the distal limbs may be effective in colling the hooves under $10^{\circ} \mathrm{C}$, but these are difficult to use in laminitic horses which should have the opportunity to lie down. In the clinical setting, a common cooling method of combining cold packs with the constant low temperature of icewater-immersion, can be achieved by using ice water bags made from plastic rectal glooves which are fixed around the equine distal limb. Several bags placed from hoof to carpus secured by gaiters offer a tight contact of the icewater-immersion to the limb and can also be used in the lying horse. However, the effectiveness of this approach in cooling hooves sufficiently is not known. Hoof temperature may be measured either invasively using thermistor needles (Worster et al. 2000) and implanted probes (Pollitt and van Eps 2004), or externally using thermistors on the outside hoof wall (Hood et al 2001) or by thermography (Turner et al. 1991). While thermography is restricted to the surface temperature and is influenced by environmental temperature and external influences like wet horn or dirt, it offers accurate measurements without invasive manipulation of the horse.

Therefore this experimental study is designed to measure the temperature of hooves during icewater-immersion bag application in sound horses, comparing the surface temperature of both front hooves, one cooled and one control hoof.

\section{Material and methods}

Horses

Six adult sound horses, belonging to the Veterinary University of Vienna are used for the study. The horses were free from hoof diseases and were stabled over night for acclimatization.

\section{Thermography}

The thermocamera "VarioCam basic" " was used to measure the surface temperature of both front hooves. At each measurement, both a dorsal and lateral picture was taken at a horizontal distance of about $30 \mathrm{~cm}$ from the hooves (Fig. 1).

\section{Study design}

The hoof walls of both front hooves were controlled for dryness and dry cleaned. Small screw heads were glued to the hoof wall below the coronary band (border between soft to hard horn) slightly lateral to the dorsal wall to act as reference points for the thermographic analysis. These screw heads were touched with an ice cube before each thermographic recording to show a distinct reference point in each thermogram. Ice water bags were applied to the left front limbs of each horse and the right limbs remained uncooled as control limbs. Three ice bags were made from rectal gloves for each left limb, closed with knots before the hand section, filled with $600 \mathrm{~g}$ crushed ice and $200 \mathrm{~g}$ cold water and closed by another knot. They were placed around the pastern, proximal to the fetlock joint and around the cannon bone with as much contact to the skin as possible. A commercially available gaiter was used to secure all bags and remained there for 90 minutes. Thermographic images were taken before the appli-
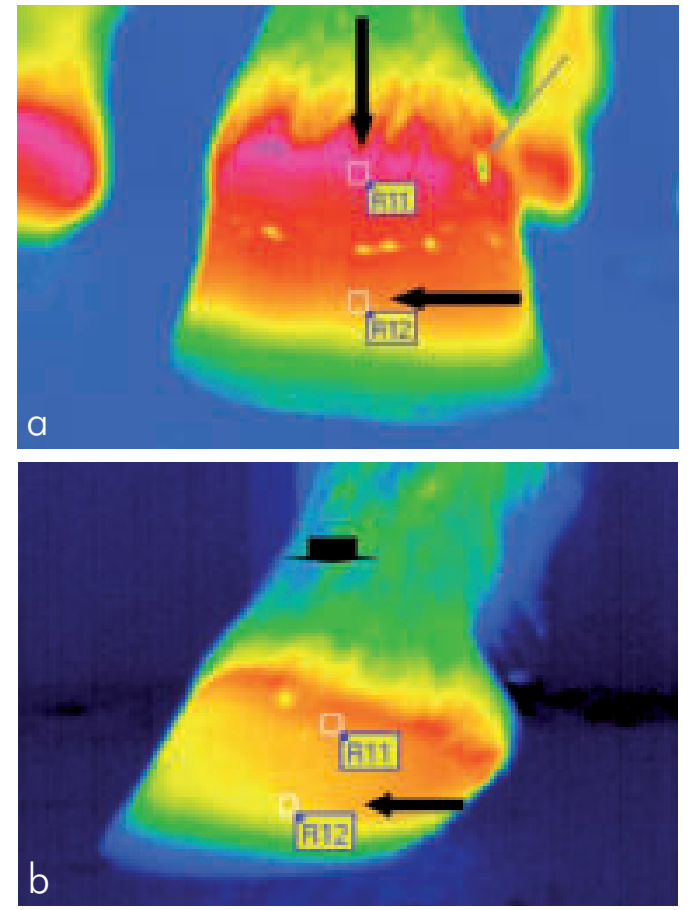

Fig. 2 Typical thermogram of the hoof showing the reference marker at the coronary band (grey arrow) as well as the analyses areas (black arrows) dorsal (a) and lateral (b). 
cation of the ice bags, during cooling at 10, 20, 40, 60, 90 min and after removal of the bags at 10,20,40,60, and 90 min following ice bags removal. The right control limb was measured before cooling, after removal and $90 \mathrm{~min}$ after removal of the bags.

\section{Data analysis}

Four locations at each hoof were analysed for their temperature: two sites for the dorsal picture and two for the lateral picture. For the dorsal picture, the sites were at the dorsal midline at the height of the reference marker and at the dorsal midline half way down the wall. For the lateral picture, the sites were proximal at the height of the reference marker, and halfway down along a line parallel to the dorsal wall. Using the software program ${ }^{2}$ of the camera, mean values within a $0.4 \mathrm{~cm}^{2}(5 \times 5$ pixels) region of interest (ROI) area at each measurement location were determined for the analysis (Fig.

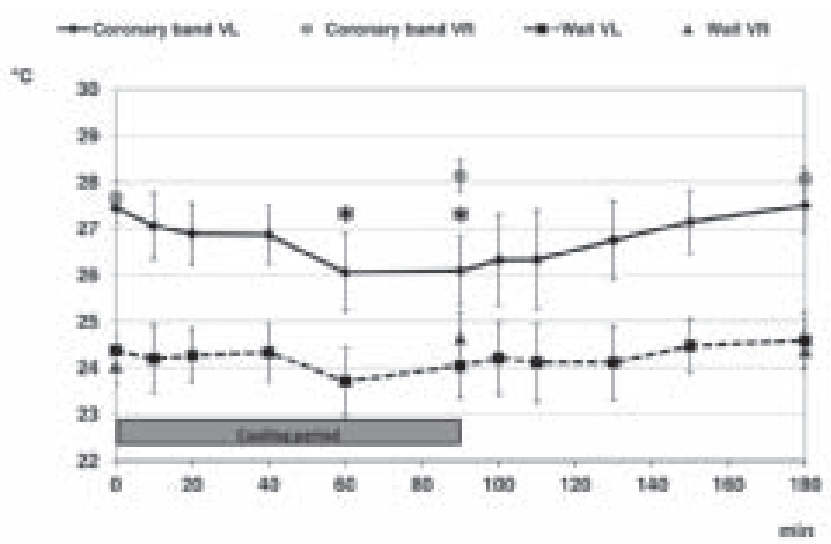

Fig. 3 Mean (SD) hoof surface temperature changes in 6 horses before and during 90 min icebag cooling and 90 min rewarming of the left hoof as well as temperature of the right control hoof. ${ }^{*}$ indicate significant cooling levels, $p<0.05$.

$2 a$ and b). The proximal points were combined to represent the coronary value, similarly the distal points were combined to represent the midwall value.

\section{Statistical analysis}

The software program SPSS was used for statistical analysis. A two way ANOVA was used to analyse the influence of time and limb. If significant, post-hoc paired t-tests were used to compare the temperature between different time instants as well as left and right limb. For all analyses, values of $p<0.05$ were considered statistically significant.

\section{Results}

All horses tolerated the application of the ice bags with the gaiters well, they moved freely within the box and no gaiter or ice bag was destroyed or displaced during the test period. All bags still contained some ice pieces after the 90 min application. The hoof temperature at the left coronary band before cooling was $27.5^{\circ} \mathrm{C}$ and reduced significantly within $90 \mathrm{~min}$ to $26.1^{\circ} \mathrm{C}$ in the left limb (Fig. 3). After remo$\mathrm{val}$ of the ice bags the hoof regained the starting temperature gradually after $90 \mathrm{~min}$. The control right limb showed a slight increasing temperature from $27.7^{\circ} \mathrm{C}$ to $28.1^{\circ} \mathrm{C}$. The temperature at the distal measurement point, the mid wall, did not change significantly with cooling and stayed around $24.4^{\circ} \mathrm{C}$.

\section{Discussion}

An important reason to find an effective and easy application of cryotherapy is the frequent and prolonged use within a clinical setting, where veterinarians, students, nursing staff and horse owners work together in the caring for the horse. The described icewater-immersion bags are easy to prepare with little material needs. They also proved to keep intact during the application period and offer an constant applied temperature of 0 to $4^{\circ} \mathrm{C}$ during at least 90 to $120 \mathrm{~min}$. The horses accept the bags and gaiters without any resistance and can lie down and get up as they like it.

The thermographic evaluation proved a significant cooling effect at the coronary band of the hooves of about $2{ }^{\circ} \mathrm{C}$ compared to the contralateral limb. Despite being statistically significant, this amount of temperature decrease on the hoof surface was disappointing. Even if each temperature decrease may cause a decrease of metabolism within the laminae and have a beneficial effect (van Eps 2010b), the proposed laminar temperature of $10^{\circ} \mathrm{C}$ was most probably not reached. The method described here aimed to cool the blood supply to the hoof rather than cooling the hoof directly. Therefore the external thermographic evaluation of the hoof wall underestimated the internal laminar temperature, but the difference between laminar temperature and surface temperature is unknown and depending on the location at the hoof. The exact temperature of the dorsal laminae could be evaluated only using invasive methods, which were not chosen in this study due to ethical reasons.

However, the temperature decrease caused by the icewaterimmersion bag was obviously limited and did not reach cooling effects of direct cooling in an ice water bath, as described by van Eps and Pollitt (2009). Therefore, in horses without problems to stand within the confined stocks during a period of 48 to 72 hours, the use of this bath is to be preferred to achieve optimal laminitis prevention. In patients already showing acute laminitis symptoms, where lying down is beneficial for the horses, an application of described ice water-immersion bags may be practically and beneficial too. The development and introduction of devices achieving both maximal cooling effect and possible application also in lying horses would be ideal and should be an important issue.

\section{Manufacturer's addresses}

1 Infratec $\mathrm{GmbH}$, Dresden, Germany

2 IRBIS $^{\circledR}$, Infratec $\mathrm{GmbH}$, Dresden, Germany 


\section{Literatur}

Belknap J. K. (2010) The pharmacologic basis for the treatment of developmental and acute laminitis. Vet. Clin. Equine 26, 115-124

Hood D. M., Wagner I. P. and Brumbaugh G. W. (2001) Evaluation of hoof wall surface temperature as an index of digital vascular perfusion during the prodromal and acute phases of carbohydrate-induced laminitis in horses. Am. J. Vet. Res. 62, 1167-1172

Kaneps A. J. (2000) Tissue Temperature Response to Hot and Cold Therapy in the Metacarpal Region of a Horse. AAEP-Proceedings 46, 208-213

Kasashima Y., Eto D. and Kusano K. (2001) Comparison of the Method of Cold Therapy to Equine Limbs after Training, with the Aim of Preventing Tendinitis. J. Equine Sci. 12, 96

Moore R. M. (2008) Evidence-Based Treatment for Laminitis - What Works? Journal of Equine Vet. Sci. 28, 176-179

Moore J. N. and Belknap J. K. (2009) You say lamellae, I say laminae, let's call... An overview of the Havermeyer workshop on laminitis pathophysiology. Vet. Immunol. Immunopathol. 129, 149150

Orsini J., Galantino-Homer H. and Pollitt C. C. (2009) Laminitis in Horses: Through the Lens of Systems Theory. Equine Vet. Sci. 29, 105-114

Petrov R., Macdonald M. H., Tesch A. M. and van Hoogmoed L. (2003) Influence of topically applied cold treatment on core temperature and cell viability in equine superficial digital flexor tendons. Am. J. Vet. Res. 64, 835-844

Pollitt C. C. (2007) Laminitis: What treatment at what stage. 10th Geneva Congress of Equine Medicine and Surgery

Pollitt C. C. and van Eps A. W. (2004) Prolonged, continuous distal limb cryotherapy in the horse. Equine Vet. J. 36, 216-220

Purohit R. C. and Mc Coy M. D. (1980) Thermography in the Diagnosis of Inflammatory Processes in the Horse. Am. J. Vet. Res. 41, 1167-1174

Ramey D. W. (1999) Cold Therapy in the Horse. Equine Pract. 21, $19-21$
Turner T. A., Wolfsdorf K. and Jourdenais J. (1991) Effects of heat, cold, biomagnets and ultrasound on skin circulation in the horse. Proceedings AAEP 37, 249-257

USDA (2000) Lameness and Laminitis in U.S. Horses. USDA:APHIS:VS, CEAH, National Animal Health Monitoring System. Fort Collins, CO, \#N318.0400. April 2000.

Van Eps A. W. and Pollitt C. C. (2004) Equine laminitis: cryotherapy reduces the severity of the acute lesion. Equine Vet. J. 36, 255260

Van Eps A. W., Walters L. J., Baldwin G. I., McGarry M. and Pollitt C. C. (2004) Distal Limb Cryotherapy for the Prevention of Acute Laminitis. Clinical Techniques in Equine Pract. 3, 64-70

Van Eps A. W. and Pollitt C. C. (2009) Equine laminitis model: cryotherapy reduces the severity of lesions evaluated seven days after induction with oligofructose. Equine Vet. J. 41, 741-746

Van Eps A. W (2010a) Acute laminitis: Medical and supportive therapy. Vet. Clin. Equine 26, 103-114

Van Eps A. W (2010b) Therapeutic hypothermia (Cryotherapy) to prevent and treat acute laminitis. Vet. Clin. Equine 26, 125-133.

Worster A. A., Gaughan E. M. and Hoskinson J. (2001) Effects of External Thermal Manipulation on Laminar Temperature and Perfusion of the Equine Digit. AAEP-Proceedings 47, 329-333

A. Prof. Dr. H. H. Florian Buchner

Klinik für Pferde

Dept für Kleintiere und Pferde

Veterinärmedizinische Universität Wien

Veterinärplatz 1

1210 Wien

Austria

florian.buchner@vetmeduni.ac.at 